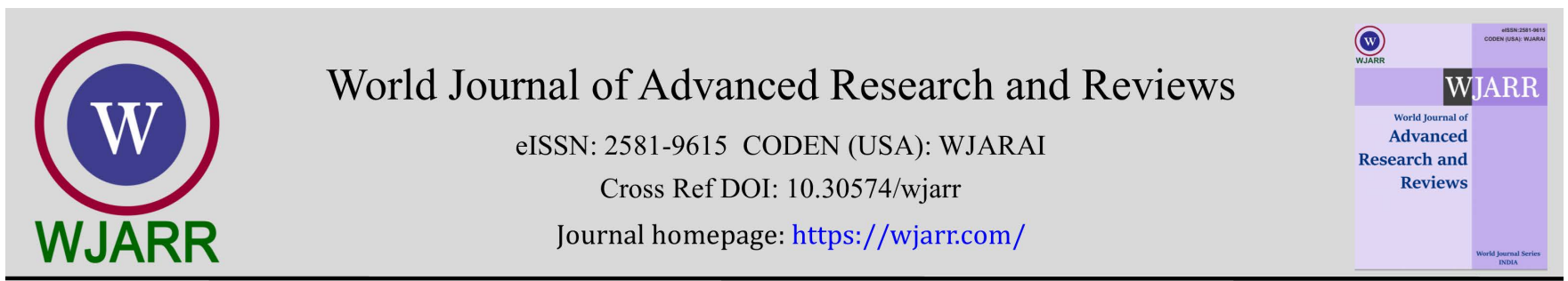

(RESEARCH ARTiClE)

\title{
Employee attitude towards communication effectiveness at state-owned enterprises in Indonesia
}

\author{
Fauzia Agustini ${ }^{1}$, Dita Amanah 2,* and Dedy Ansari Harahap ${ }^{3}$ \\ ${ }^{1}$ Entrepreneurship Study Program, Faculty of Economics, Universitas Negeri Medan, Medan, Indonesia. \\ 2 Business Education Study Program, Faculty of Economics and Business Education, Universitas Pendidikan Indonesia, \\ Bandung, Indonesia. \\ ${ }^{3}$ Management Study Program, Faculty of Economics and Business, Universitas Islam Bandung, Bandung, Indonesia.
}

World Journal of Advanced Research and Reviews, 2022, 13(02), 389-400

Publication history: Received on 11 January 2022; revised on 17 February 2022; accepted on 19 February 2022

Article DOI: https://doi.org/10.30574/wjarr.2022.13.2.0160

\begin{abstract}
The key to the success of an organization is communication. Good communication is the communication that results in a common opinion among the perpetrators. Effective communication is important in organizations because it will make the organization grow and prosper. Organizational leader as communicator must be able to convey the intended messages to the communicants (employees). The message must be fully understood by employees. If the message is delivered properly, then the communicant will provide feedback to the expectations of communicators. This study aims to determine employee attitudes towards the effectiveness of communication in the office environment of KebonSeiBerlian PT. Perkebunan Nusantara V Riau. The sampling technique was a total sampling of 60 respondents. Data collection was carried out through literature study and questionnaire distribution. This study uses the Multi Attribute Model (MAM) model to determine employee attitudes towards the effectiveness of communication in the KebonSeiBerlian Office PT. Perkebunan Nusantara V Riau. The results showed that the attitude of employees towards the bulletin boards in the company environment was underutilized. Employees consider the success of communication that occurs between communicants and communicators. So far, the information conveyed by employees to superiors and coworkers has not experienced problems so that communication is well established.
\end{abstract}

Keywords: Employee Attitudes; Communication Effectiveness; PTPN V; Multi Attribute Model; Indonesia

\section{Introduction}

Companies need to pay attention to employee behavior that is reflected in employee attitudes or what is commonly known as work attitudes. A person can have various attitudes; they are positive or negative attitudes about aspects of work. Boone et al, describes attitude as an assessment or tendency of actions or feelings that are favorable or unfavorable to objects or data [1]. Then Inuwa argues that attitude is characterized by a person's evaluation and belief in what he observes [2]. In addition, Turnstone Qurtubi defines attitude as affection or feeling for or against a stimulus [3]. Positive feelings can be reflected in one's satisfaction with work. Chan, in his research states that there is a positive and significant influence between work attitudes on job satisfaction [4]. Likewise, research conducted Hardiansyah et al, states that there is a positive and significant effect of work attitudes on job satisfaction [5]. Based on these results, it shows that employee attitudes or work attitudes are important because they can affect job satisfaction and employee performance.

\footnotetext{
${ }^{*}$ Corresponding author: Dita Amanah

Business Education Study Program, Faculty of Economics and Business Education, Universitas Pendidikan Indonesia, Bandung, Indonesia.
}

Copyright (C) 2022 Author(s) retain the copyright of this article. This article is published under the terms of the Creative Commons Attribution Liscense 4.0. 
If the employee is satisfied with his job, this will also affect the employee's performance. This shows that work attitude can affect employee performance. Employees are the main assets of the organization and have a strategic role as thinkers, planners and controllers of organizational activities through sustainable human resource empowerment placing jobs in the right position will make it easier for employees to carry out their duties and minimize the occurrence of unwanted errors by the company [6], [7], [8]. Motivated workers will make employees willing and direct their desires in completing their responsibilities so that workers and company goals can be achieved [9]. Through the knowledge and skills possessed by employees, the company continues to forge it through education and training so that the process of transferring knowledge and sharing knowledge is able to create knowledgeable workers who play a role in employee innovation and creativity[10]. As in research Moon et al, it is said that work attitudes have a direct effect on employee performance [11]. Likewise, research conducted Jimenez states that work attitudes have a positive and significant effect on employee performance [12].

According to the research results of Subagio, it shows that work attitudes have a direct effect on the motivation and performance of PT Ithacca Resources employees [13]. Subakti also states that there is an influence of work attitudes on employee performance at Cafe X Bogor [14]. Employee attitudes are reflected in aspects or activities of employees in a company. Work attitudes according to Agustini are positive or negative evaluative statements that employees have about aspects of their work environment. One of these aspects includes communication between superiors and subordinates as well as fellow employees [15].

Communication according to Silviani is the delivery or exchange of information from sender to recipient, either verbally, in writing, or using communication tools. In a company, communication is very important in achieving company goals [16]. Smooth duty is closely related to the smooth communication that occurs in the company. Research Agustini et al, shows that communication has an effect on employee job satisfaction [17]. Likewise Fattah in his research, it shows that communication affects employee job satisfaction [18]. Job satisfaction arises when the employee feels that what he gets from the company is proportional to the contribution he has made. In other words, job satisfaction is an assessment of attitudes and emotional reactions that result from employees' perceptions of how well their workers meet their needs and matters that are considered important [19]. Communication that is needed in the company is effective communication, namely communication that always occurs as coordination between superiors and subordinates as well as fellow colleagues. Duha which states that to realize job satisfaction, effective communication is needed [20].

Attitudes are evaluations, feelings and tendencies of a person who are relatively consistent with an object or idea. Attitude will put someone into a thought of liking or disliking something, moving toward or away from that something [21]. Attitudes according to Robbins et al, are evaluative statements, both pleasant and unpleasant towards, objects, individuals, or events [22]. This reflects how someone feels about something. For example, attitudes towards the type of work and attitudes towards fellow employees. Work attitude shows the relationship between the subject and the work object which aims to see the difference between employee work attitudes and others. The work attitude has a clear direction, namely both towards people's objects and ideas.

Work attitudes according to Scandura as a tendency to think and feel satisfied or dissatisfied with work [23]. An indication that employees who are satisfied with their work will work, be honest and not lazy, and participate in advancing the company. On the other hand, employees who are dissatisfied with their work will work arbitrarily, work if there is supervision, are dishonest, which in turn is detrimental to the company. Meanwhile, according to Beugré explaining that work attitude is the action that the employee will take and everything that the employee must do, which results are proportional to the effort done [24]. For example, if the division of responsibilities between top management and employees from a job perspective, the two are clearly different. Management must be responsible for the product or service, but employees are only responsible for the process of making the product or service.

Factors that affect work attitudes according to Wine et al, argue that are as follows [25]:

\section{- Working Conditions}

Work situations that include physical or social environments that guarantee will affect comfort at work. A sense of comfort will affect employee morale and quality.

\section{- Supervisory Supervisor}

A leader who supervises employees properly and attentively is generally able to influence employee attitudes and morale. 


\section{- $\quad$ Cooperation from Colleagues}

Having co-workers who can work together really supports the quality and achievement of completing work.

- Security

A sense of security is created and an environment that is maintained will guarantee and increase peace at work.

- Opportunities for Advancement

There is a guarantee for a better future in terms of career, both promotion and old age security.

\section{- Work Facilities}

The availability of facilities that are used by employees in their work.

- Salary

Pleasure with the rewards provided by the company, both in the form of basic salary, benefits, and so on, will affect the attitude of employees in completing their work.

There are three kinds of attitudes according to McShane et al, [26]. These attitudes are job satisfaction, organizational commitment and job involvement. The following is a description of these attitudes.

\section{- Job Satisfaction}

The term job satisfaction (job satisfaction) can be defined as a positive feeling about one's job which is the result of an evaluation of its characteristics. A person with a high level of job satisfaction has positive feelings about the job, while someone who is dissatisfied has negative feelings about the job. According to Agustini, job satisfaction is a form of a person's feelings about their work, work situations, and their relationships with colleagues [27].

\section{- Job Involvement}

Job Involvement measures the degree to which individuals psychologically side with their work and considers the level of performance achieved as a form of self-reward. Employees who have a high level of job involvement are very impartial and really care about the field of work they are doing.

\section{- $\quad$ Organizational Commitment}

Organizational commitment, which is defined as a condition in which an employee sides with a particular organization and its goals and desires to maintain membership in the organization. Organizational behavior according to Cooper et al, is a component of behavior [28]. Organizational commitment is a situation where an employee sides with an organization and its goals, and intends to maintain its membership. High someone's involvement in a job means taking sides with the particular job of an individual, while high organizational commitment means siding with the organization that recruits the individual. Thus, high job involvement means taking sides with an individual's particular job, while high organizational commitment means siding with the organization that recruits that individual.

Employee attitudes are measurable individual behavior. And is a comprehensive evaluation of a particular object. The indicators for employee attitudes according to Agustini et al, can be measured from the attitude of employees towards the following factors [29].

\section{- $\quad$ The work itself}

It is a job that is usually done by these employees; this can be measured from the workload, working hours, and soon. 
- Co-workers

That is, employees who have the same level / level of position, this can be measured through cooperation, communication, and so on.

- Bosses

Is someone who has a higher level and has greater power than his subordinates? This can be measured from communication, assigned tasks.

- $\quad$ The physical environment of the company

There are around or in the company room such as, lighting, atmosphere, and so on.

- $\quad$ Rules of norms that apply to the company

Things that regulate and bind employees to the company. For example, company regulations.

- $\quad$ Programs implemented by the company

That is a short-term plan made for employee self-development such as pension plans, compensation and soon.

Communication is an important part of working life, especially in forming an effective and efficient organization. Therefore, an open communication relationship must be created in the organization. Terminologically, communication means the process of delivering a statement by one person to another. From this understanding, it is clear that communication involves a number of people where one person states something to another [30].

According to Thompson communication is the process of transferring understanding in the form of ideas on information from one person to another [31]. This transfer of meaning involves more than just the words used in conversation, facial expressions, intonation, and so on. According to Hawkins [32], Communication is a process of exchanging information between individuals through an ordinary system, either with symbols, signals, or behavior or actions.Based on the previous explanations, it can be concluded that communication is the delivery of information from one person to another and the interaction process occurs between a number of people who intend to provide an understanding of the information to be conveyed either orally or in writing.

Although all organizations must communicate with various parties in achieving their goals, it is important to know that the approach used between one organization and another can vary or vary. According to Coleman the types of communication are [33]:

\section{- $\quad$ Top-down communication}

A manager who uses the downward line of communication has the goal of conveying information, directing, coordinating, motivating, leading, and controlling various activities at the lower level. The line of communication from the top (manager) to the bottom (employees) is the delivery of messages that can be in the form of instructions, instructions, and procedures to be carried out by subordinates as well as possible. To achieve the desired goals, it is necessary to pay attention to the use of the same language, simple, straightforward, and easy to und erstand in conveying messages.

\section{- Bottom-up communication}

In an organizational structure, bottom-up communication means the message flow is conveyed from below (employees) to the top (managers). The message that you want to convey first comes from the employee which is then conveyed to a higher line. 


\section{- Horizontal communication}

Horizontal communication or often referred to as lateral communication is communication between parts that have an equal position in an organization. The objectives of horizontal communication are, among others, to persuade, influence and provide information to sections or departments that have an equal position.

\section{- Diagonal communication}

Diagonal communication is communication that involves 2 different organizational levels, for example, the communication that exists between HR managers and financial employees.

According to Kelly there are 5 aspects that must be understood in building effective communication, namely [34]:

- $\quad$ Clarity (clarity), language and the information conveyed must be clear.

- Accuracy, language and information conveyed must be truly accurate or precise.

- The context (Context), language and information to be conveyed must be in accordance with the circumstances and environment in which communication occurs.

- Studying the culture, culture or habits of people or society also needs to be considered in communicating.

- Understanding the language, by understanding the language of others means we try to respect other people.

Communication that runs smoothly and effectively can be seen from the effects after communication. If the message or information received gets the right response by the communicant, it means that the information can be received very well. According to Strachan, there are several indicators of effective communication, namely [35]:

\section{- Understanding}

Ability to understand messages carefully as intended by the communicator. The purpose of communication is the occurrence of common understanding, and to that end, a communicator and a communicant must mutually understand their respective functions. Communicators are able to convey messages while communicants are able to receive messages conveyed by communicators.

\section{- $\quad$ Pleasure}

If the communication process is not only successful in conveying information, it can also take place in a pleasant atmosphere for both parties. An atmosphere that is more relaxed and pleasant will be more pleasant to interact with when compared to a tense atmosphere because communication is flexible. With such an atmosphere, an interesting impression will arise.

\section{- Influence on attitude}

The purpose of communication is to influence attitudes. If by communicating with other people, then there is a change in behavior, then the communication that occurs is effective, and if there is no change in a person's attitude, then the communication is not effective.

\section{- Good relationship}

That in the process of effective communication accidentally increases the level of interpersonal relationships. Often if people have the same perception, the similarity of character, match; by itself the relationship will happen well.

- Action

Communication will be effective if both parties communicate about an action.

According to Newstrom there are several indicators that are most important in communication [36]. These indicators are: 


\section{- $\quad$ Communicator / sender}

the communicator or sender is a person who has the information and the will to convey it to others. Communicators in the company are usually leaders or subordinates.

- Channels

the channel which is commonly called the media is a tool by which messages move from sender to receiver. Channels are the paths through which information physically passes. Some of the main channels include: television, radio, computer / internet networks, newspapers, magazines, books and so on.

- Message / symbol

Message / symbol is information that the sender wants to convey to the recipient and is mostly in the form of words, both in the form of speech or in writing.

\section{- $\quad$ Communicate / recipient}

Communicant / recipient is the person who receives information from the sender. The receiver performs the process of interpreting the information received from the sender.

\section{Material and methods}

This research was conducted at the KebonBerlian Office of PT. Perkebunan Nusantara V Riau. The sample consisted of 60 respondents who were employees of this office. Analysis of employee attitudes was carried out using Fishbein's Multi Attribute Model, with the following formula:

$$
\text { Ao }=\Sigma(\text { bi x ei })
$$

Explanations

Ao: employee attitude

bi: employee beliefs

ei: employee evaluation of communication effectiveness

$\Sigma$ : the sum of a number of attributes I

All results from the Multi Attribute Model are entered into the Excel program which is then analyzed by the categ ories of attitudes that employees have towards the effectiveness of communication in this office.

\section{Results}

\subsection{Respondent Characteristics}

Employees' Attitudes towards Communication Effectiveness at the KebonSeiBerlian Office of PT. Perkebunan Nusantara V Riau. In this study using a multi-attribute model to see employee attitudes towards the effectiveness of communication at the KebonSeiBerlian Office PT. Perkebunan Nusantara V Riau. As for the attributes used to measure employee attitudes towards communication effectiveness, namely:

- Understanding of the information submitted by superiors

- Understanding of the information conveyed by colleagues

- The accuracy of the information received from superiors / colleagues

- A notice board as a means of conveying information in the office

- Smooth internet network as access to information in an office environment

- The smoothness of the information conveyed through the Cellphone in the office environment

- The use of Indonesian in information circulating in the office environment

- The suitability of information with the work context in the office environment

- Clarity of information circulating in the office environment

- Understanding of the information provided to superiors 
- Comprehension of the information provided to colleagues

- The accuracy of the information provided to superiors / colleagues

Table 1 Respondent Characteristics

\begin{tabular}{|l|l|l|l|}
\hline \multirow{2}{*}{ Personal Data } & \multicolumn{2}{|l|}{ Total } & Percentage \\
\hline \multirow{3}{*}{ Ages } & Male & 43 people & $72 \%$ \\
\cline { 2 - 4 } & Female & 17 people & $28 \%$ \\
\hline \multirow{3}{*}{ Education } & $30-39$ years & 21 people & $21 \%$ \\
\cline { 2 - 4 } & $40-49$ years & 31 people & $51 \%$ \\
\cline { 2 - 4 } & $>50$ years & 17 people & $28 \%$ \\
\hline \multirow{3}{*}{ Status } & High School & 58 people & $97 \%$ \\
\cline { 2 - 4 } & Diploma & 0 people & $0 \%$ \\
\cline { 2 - 4 } & Bachelor & 2 people & $3 \%$ \\
\hline \multirow{3}{*}{ Years of service } & Married & 60 people & $100 \%$ \\
\cline { 2 - 4 } & Single & 0 people & $0 \%$ \\
\cline { 2 - 4 } & $<3$ years & 0 people & $0 \%$ \\
\cline { 2 - 4 } & $2-5$ years & 0 people & $0 \%$ \\
\cline { 2 - 4 } & $>5$ years & 60 people & $100 \%$ \\
\hline & Source: Data Processing Results \\
\hline
\end{tabular}

Based on this multi-attribute model, employees have confidence (believe, bi) and evaluation (evaluation, ei). Trust is the believed possibility of the relationship between an object and its relevant characteristics. Evaluation reflects how well consumers rate a feature.

\subsection{Level of confidence (believe, bi)}

Table 2 Employee Confidence Levels on Attitude Attributes of Employees at KebonSeiBerlian Office PT. Perkebunan Nusantara V Riau

\begin{tabular}{|l|l|c|c|}
\hline No. & Attributes & $\begin{array}{c}\text { Level } \\
\text { Confidence }\end{array}$ & Order \\
\hline 1 & Understanding of information submitted by superiors & 8.32 & 10 \\
\hline 2 & Understanding of the information submitted by colleagues & 8.38 & 9 \\
\hline 3 & The accuracy of the information you receive from superiors / co-workers & 8.23 & 12 \\
\hline 4 & Noticeboard as a means of conveying information in the office & 8.26 & 11 \\
\hline 5 & $\begin{array}{l}\text { The smooth operation of the internet network as access to information in an office } \\
\text { environment }\end{array}$ & 8.45 & 7 \\
\hline 6 & The fluency of information conveyed via cell phone in an office environment & 8.51 & 5 \\
\hline 7 & The use of Indonesian in information circulating in the office environment & 8.57 & 4 \\
\hline 8 & Suitability of information with the work context in the office environment & 8.40 & 8 \\
\hline 9 & Clarity of information circulating in an office environment & 8.63 & 3 \\
\hline 10 & Understanding of the information provided to superiors & 8.79 & 2 \\
\hline 11 & Comprehension of information provided to co-workers & 8.47 & 6 \\
\hline 12 & The accuracy of the information provided to superiors / colleagues & 8.94 & 1 \\
\hline
\end{tabular}


The level of trust is the value of the employee's trust or confidence in the attributes used to measure employee attitudes towards communication effectiveness. The results showed the value of trust in each attribute of employee attitudes towards the effectiveness of communication at the KebonSeiBerlian Office PT. Perkebunan Nusantara V Riau provided by 60 employees. As shown in Table 2 .

Table 2 shows the accuracy of the information provided to superiors / coworkers is the attribute trusted by employees in the first order (1) with the highest value of 8.94 compared to other attributes. However, the accuracy of the information received from superiors / coworkers is the twelfth attributes (12) with the lowest value, namely 8.23.

\subsection{Level of Evaluation (evaluation, ei)}

The results showed the value of the evaluation of each attribute of employee attitudes towards the effectiveness of communication at the KebonSeiBerlian Office PT. Perkebunan Nusantara V Riau. As seen in Table 3.

Table 3 Employee Evaluation Level of Employee Attributes at KebonSeiBerlian Office PT. Perkebunan Nusantara V

\begin{tabular}{|c|c|c|c|}
\hline No. & Attributes & $\begin{array}{l}\text { Level of } \\
\text { Evaluation }\end{array}$ & Order \\
\hline 1 & Understanding of information submitted by superiors & 2.40 & 4 \\
\hline 2 & Understanding of the information submitted by colleagues & 2.19 & 10 \\
\hline 3 & The accuracy of the information you receive from superiors / co-workers & 2.34 & 7 \\
\hline 4 & Noticeboard as a means of conveying information in the office & 2.13 & 11 \\
\hline 5 & $\begin{array}{l}\text { The smooth operation of the internet network as access to information in an } \\
\text { office environment }\end{array}$ & 2.13 & 12 \\
\hline 6 & The fluency of information conveyed via cell phone in an office environment & 2.28 & 8 \\
\hline 7 & The use of Indonesian in information circulating in the office environment & 2.47 & 2 \\
\hline 8 & Suitability of information with the work context in the office environment & 2.40 & 5 \\
\hline 9 & Clarity of information circulating in an office environment & 2.28 & 9 \\
\hline 10 & Understanding of the information provided to superiors & 2.43 & 3 \\
\hline 11 & Comprehension of information provided to co-workers & 2.38 & 6 \\
\hline 12 & The accuracy of the information provided to superiors / colleagues & 2.51 & 1 \\
\hline
\end{tabular}

In Table 3 it can be seen that the accuracy of the information provided to superiors / colleagues is the highest value, namely 2.51 compared to other attributes. Meanwhile, the attribute of internet network fluency and noticeboards as a means of delivering information is the lowest evaluation value with a value of 2.13 .

\subsection{Employees' attitude towards effectiveness}

From the results of the multiplication between trust and evaluation for each attribute (multi-attribute model), it is found that the results are as in Table 4 below, which is the employee's attitude towards communication effectiveness.

Attitudes of employees towards the effectiveness of communication at the KebonSeiBerlian Office of PT. Perkebunan Nusantara V Riau in Table 4 shows that the accuracy of the information provided to superiors / coworkers is an attribute that has a high value, namely 22.24 compared to other attributes which are in the first order (1). while the attribute Notice board as a means of conveying information in the office is the lowest order attribute with a value of 17.59. 
Table 4 Results of Employee Attitudes

\begin{tabular}{|c|c|c|c|c|c|}
\hline No. & Attributes & $\begin{array}{c}\text { Level of } \\
\text { Confidence }\end{array}$ & $\begin{array}{c}\text { Level of } \\
\text { Evaluation }\end{array}$ & Attitude & Order \\
\hline 1 & Understanding of information submitted by superiors & 8.32 & 2.40 & 19.97 & 6 \\
\hline 2 & $\begin{array}{l}\text { Understanding of the information submitted by } \\
\text { colleagues }\end{array}$ & 8.38 & 2.19 & 18.35 & 10 \\
\hline 3 & $\begin{array}{l}\text { The accuracy of the information you receive from } \\
\text { superiors / co-workers }\end{array}$ & 8.23 & 2.34 & 19.26 & 9 \\
\hline 4 & $\begin{array}{l}\text { Noticeboard as a means of conveying information in the } \\
\text { office }\end{array}$ & 8.26 & 2.13 & 17.59 & 12 \\
\hline 5 & $\begin{array}{l}\text { The smooth operation of the internet network as access } \\
\text { to information in an office environment }\end{array}$ & 8.45 & 2.13 & 18 & 11 \\
\hline 6 & $\begin{array}{l}\text { The fluency of information conveyed via cell phone in an } \\
\text { office environment }\end{array}$ & 8.51 & 2.28 & 19.4 & 8 \\
\hline 7 & $\begin{array}{l}\text { The use of Indonesian in information circulating in the } \\
\text { office environment }\end{array}$ & 8.57 & 2.47 & 21.17 & 3 \\
\hline 8 & $\begin{array}{l}\text { Suitability of information with the work context in the } \\
\text { office environment }\end{array}$ & 8.40 & 2.40 & 20.16 & 4 \\
\hline 9 & Clarity of information circulating in an office environment & 8.63 & 2.28 & 19.68 & 7 \\
\hline 10 & Understanding of the information provided to superiors & 8.79 & 2.43 & 21.36 & 2 \\
\hline 11 & Comprehension of information provided to co-workers & 8.47 & 2.38 & 20.16 & 5 \\
\hline 12 & $\begin{array}{l}\text { The accuracy of the information provided to superiors / } \\
\text { colleagues }\end{array}$ & 8.94 & 2.51 & 22.24 & 1 \\
\hline
\end{tabular}

\section{Discussion}

Attitudes usually play a major role in shaping behavior. Attitude towards communication effectiveness is the result of evaluation of communication that occurs within a company. The smoothness of communication in a company is the main thing in helping the smooth running of tasks.

This study has measured the effectiveness of communication which consists of 4 (four) main indicators, namely communicators, communication channels, messages / symbols and communicants. The results of research that have been conducted indicate that employees perceive the bulletin board, which is a communication channel in the office, as less functioning as a means of delivering information. This shows that in the KebonSeiBerlian Office, PT. Perkebunan Nusantara V Riau tends to use face to face or in person in delivering information. Even though the more variety of media used by communicating parties (both sources and beneficiaries), will have a very good effect because in addition to the amount of information being more complete, it is usually also more quality / increasingly provides clarity to the information it receives [37].

Furthermore Sanina et al, states that government organizations need to choose the right composition of various communication channels to achieve the most efficient results [38]. This shows that companies need various communication channels in order to achieve effective communication. This is in line with the opinion Mamuli et al, which states that there is a need for variation in communication channels by adding new communication channels for companies [39].

KebonSeiBerlian Office Employees PT. Perkebunan Nusantara V Riau considers the success of communication that occurs between communicants and communicators. So far, the information conveyed by employees to superiors and coworkers has not experienced problems so that communication is well established. This results in smooth communication that occurs so that there is no misunderstanding or misunderstanding between the two parties [40]. Supported by Awad et al, who revealed that employees are happy with their colleagues and superiors [41]. Strong 
communication bonds promote healthier interpersonal relationships. The creation of the organization's vision and mission involves employees and company values developed by the organization.

The existence of effective interpersonal communication can improve employee performance and organizational productivity. Furthermore Ghofar et al, also stated that interpersonal communication can improve employee performance [42]. This is in line with Singh et al, who argue that organizational functions can be improved through a good understanding of interpersonal communication [43]. The leader of an organization must have interpersonal communication skills so that organizational performance increases. Assertiveness strategies must be applied in communicating by superiors to subordinates.

\section{Conclusion}

The results of the research that have been conducted indicate that the attitude of employees towards the bulletin boards in the company environment is not well utilized. Employees view the notice board, which is a communication channel in the office, as less functioning as a means of conveying information.

KebonSeiBerlian Office Employees PT. Perkebunan Nusantara V Riau considers the success of communication that occurs between communicants and communicators. So far, the information conveyed by employees to superiors and coworkers has not experienced problems so that communication is well established.

There needs to be a variety of communication channels so that communication can run effectively. So far, only face-toface communication is carried out at the KebonSeiBerlian Office of PT. Perkebunan Nusantara V Riau. In order for communication in an office environment to be effective, there is a need for additional communication channels, such as using e-mail as one of the communication channels in the office environment.

\section{Compliance with ethical standards}

\section{Acknowledgments}

Thank you to all the authors who have participated in the completion of writing this article.

\section{Disclosure of conflict of interest}

Authors declare that there is no conflict of interest.

\section{Statement of informed consent}

Our respondents have read and understand the provided information in the questionnaire and have willing to answer it. They are voluntary, without being given any fees.

\section{References}

[1] LE Boone, DL Kurtz, S Berston. Contemporary Business, 18th ed. New Jersey: Wiley. 2019.

[2] M Inuwa. The Impact of Job Satisfaction, Job Attitude and Equity on Employee Performance, Int. J. Bus. Manag. 2015; 3(5): 288-293.

[3] A Qurtubi, Perilaku Organisasi. Surabaya: CV. Jakad Media Publishing. 2020.

[4] SCH Chan. Participative leadership and job satisfaction: The mediating role of work engagement and the moderating role of fun experienced at work. Leadersh. Organ. Dev. J. 2019; 40(3): 319-333,.

[5] AT Hardiansyah, A Amelia, M Santika. Kepuasan Kerja Sebagai Faktor Terbentuknya Sikap Kerja Pegawai Negeri Sipil Kantor Kecamatan Klampis, Bangkalan. Kompetensi. 2018; 12(2): 167-187.

[6] H Harmen, D Amanah, DA Harahap, F Naibaho. Sources of Job Stress Dimension Effect on Employee Performance (Case in Health Social Security Organizer Agency Medan, Indonesia). East African Sch. J. Econ. Bus. Manag. 2019; 2: 9581-590.

[7] F Agustini, D Amanah, DA Harahap. Desain Model Pemberdayaan Dosen Di Kota Medan. Jurnal Manajerial. 2018; 3(5): 167-173. 
[8] C Ermiati, D Amanah, DA Harahap, F Tanjung, Pengaruh Pengembangan Karir dan Penempatan Kerja Terhadap Prestasi Kerja Karyawan pada PDAM Tirtanadi Provinsi Sumatera Utara J. MBIA. 2018; 17(3): 17-24.

[9] DA Harahap, F Agustini, D Amanah, S Riza. The Comparison of Work Motivation between Employees and Staffs Based On Two Factor Theory of Motivation in PT PP London Sumatra Indonesia At Bah Lias Research Perdagangan North Sumatera Indonesia, Int. J. Eng. Manag. Invent. 2017; 2(1): 187-192.

[10] S Suwarsi, DA Harahap, D Amanah. Maturity Analysis Of Knowledge Management Implementation On Organizational Performance (Survey On State-Owned Enterprises In Indonesia). J. Contemp. Issues Bus. Gov. $2021 ; 27(2): 5672-5682$.

[11] TW Moon, W-M Hur, YJ Choi. How leaders perceived emotional labor leads to followers job performance: A serial mediation model. J. Serv. Theory Pract. 2019; 29(1): 22-44.

[12] EC Jimenez. Emotional Quotient, Work Attitude and Teaching Performance of Secondary School Teachers. J. Pedagog. Sociol. Psychol. 2020; 2(1): 25-35.

[13] M Subagio. Pengaruh Kecerdasan Emosional, Motivasi, dan Sikap Kerja Terhadap Kinerja Karyawan Pada PT Ithaca Resources, J. Manaj. 2015; 19(1): 101-120.

[14] AG Subakti. Pengaruh Motivasi, Kepuasan, dan Sikap Kerja terhadap Kinerja Karyawan di Café X Bogor, BINUS Bus. Rev. 2013; 4(2): 596-606.

[15] F Agustini, Strategi Manajemen Sumber Daya Manusia. Medan: UISU Press. 2020.

[16] I Silviani. Komunikasi Organisasi. Surabaya: PT. Scopindo Media Pustaka. 2020.

[17] F Agustini, SY Harefa. Analisis Komunikasi Dan Pengaruhnya Terhadap Kepuasan Kerja Pegawai Pada Badan Penanaman Modal Dan Promosi Sumatera Utara, J. Penelit. Komun. Dan Pembang. 2016; 17(2): 143-154.

[18] AH Fattah. Kepuasan Kerja dan Kinerja Pegawai. Yogyakarta: Elmatera. 2017.

[19] H Harmen, D Amanah, DA Harahap. The Workload and Organizational Commitment to Job Satisfaction, Int. J. Humanit. Soc. Stud. 2020; 8(6): 205-215.

[20] T Duha, Perilaku Organisasi. Yogyakarta: Deepublish. 2018.

[21] P Žukauskas Sociodemographic Indicators: Employee Attitude. London: Intech Open. 2018.

[22] SP Robbinsm, T Judge. Organizational Behavior Whats New in Management Series, 18th ed. New York: Pearson. 2019.

[23] TA Scandura. Essentials of Organizational Behavior: An Evidence-Based Approach, 2nd ed. New York: Sage Publications. 2017.

[24] CD Beugré. The Neuroscience of Organizational Behavior. Cheltenham: Edward Elgar Publishing. 2018.

[25] B Wine, JK Pritchard. Organizational Behavior Management: The Essentials. Newport: Hedgehog Publishers. 2018.

[26] S McShane, MA Von Glinow. Organizational Behavior, 4th ed. United States: Mc Graw Hill Education. 2018.

[27] F Agustini. Manajemen Sumber Daya Manusia Lanjutan. Medan: Madenatera. 2011.

[28] CD Cooper, JWS Jr, D Hellriegel. Experiencing Organizational Behavior. Boston: Boston Academic Publishing, Incorporated d.b.a. FlatWorld. 2018.

[29] F Agustini, D Amanah, DA Harahap, M Faridj Wajdi. Human Resources Management Functions on Employee Work Motivation At State-Owned Company In Medan, Indonesia. International Journal of Education and Social Science Research. 2019; 2(6): 177-194.

[30] DA Harahap, D Amanah. Pengantar Manajemen, no. September. Bandung: Alfabeta. 2018.

[31] N Thompson. Effective Communication: A Guide for the People Professions, 2nd ed. United Kingdom: Macmillan Education. 2011.

[32] R Hawkins. Effective Communication: Beginners Guide, 1st ed. South Carolina: CreateSpace Independent Publishing Platform. 2018.

[33] K Coleman. Effective Communication: Skills and Strategies to Effectively Speak Your Mind Without Being Misunderstood. Communication \& Social Skills. California : CreateSpace Independent Publishing Platform. 2019. 
[34] A Kelly. Social Skills: Developing Effective Interpersonal Communication, 1st ed. Abingdon: Routledge. 2018.

[35] J Strachan. Communication Skills for Workplace Success: How to Practice Effective Communication in Work \& Life, Boost Your Income \& Thrive Effectively. Chicago : Independently Published. 2018.

[36] J Newstrom. Organizational Behavior: Human Behavior at Work. United States: McGraw-Hill Higher Education. 2014.

[37] SA Sufa, N Christantyawati, RAE Jusnita. Tren Gaya Hidup Sehat dan Saluran Komunikasi Pelaku Pola Makan Food Combining. J. Komun. Prof. 2017; 1(2): 105-120.

[38] A Sanina, A Balashov, M Rubtcova, DM Satinsky. The effectiveness of communication channels in government and business communication, Inf. Polity. 2017; 22(4): 251-266,.

[39] LC Mamuli, SN Mutsotso, DB Namasaka. The Influenceof Communication Channels on Management Practices in Kenyan Public Universities, Int. J. Acad. Res. Progress. Educ. Dev. 2013; 2(1): 257-267.

[40] E Okoro, M CWashington, O Thomas. The Impact of Interpersonal Communication Skills on Organizational Effectiveness and Social Self-Efficacy: A Synthesis, Int. J. Lang. Linguist. 2017; 4(3): 28-32.

[41] TA Awad, SE Alhashemi. Assessing the effectof interpersonal communicationson employees commitment andsatisfaction. Int. J. Islam. Middle East. Financ. Manag. 2012; 5(2): 134-156.

[42] A Ghofar, M Akbar, M Luddin. The Effect of Interpersonal Communication, Self Engagement and Organizational Commitment toward The Employee Performance, Int. J. Hum. Cap. Manag. 2018; 2(2): 30-44.

[43] AK Singh, Lalropuii, Role of Interpersonal Communication in Organizational Effectiveness, Int. J. Res. Manag. Bus. Stud. 2014; 1(4): 36-39. 